\title{
PENERAPAN ASSERTIVE TRAINNING (AT)/ PERILAKU ASERTIF PADA PENYALAHGUNA NAPZA DI LEMBAGA PEMASYARAKATAN KELAS IIA PEKANBARU
}

\author{
Usraleli*1 $^{*}$, Masnun ${ }^{2}$, Magdalena ${ }^{3}$ \\ ${ }^{1,2}$ Poltekkes Kemenkes Riau; Jalan Melur No 103, telp (0761)36581/fax 20656 \\ ${ }^{3}$ Program Studi D IV, Jurusan Keperawatan, Poltekkes Kemenkes Riau \\ *E-mail: usraleli@pkr.ac.id
}

\begin{abstract}
One of the trends and issues of mental health is drug abuse. The results of the Substance Abuse and Menthal Health Services Administration survey said that children aged 12-17 years 9\% used illegal substances and 18.8\% consumed alcohol in a month (Videbeck, 2008). Thought stopping is done by severing threatening thoughts or obsessions by saying "STOP" when threatening thoughts and feelings emerge and replacing those thoughts with positive thoughts. The method used is discussion, question and answer and role play / independent practice. Objective: to identify the effectiveness of Assertiveness Training (AT) / Assertive Behavior in drug users. The results showed that the ability of fostered citizens to stop negative thoughts towards the thought process before was 4, 64 and after thought stopping has done, it increases two times. Thought stopping is effective in turning negative thoughts into positive thoughts. Thought stopping therapy is effective in changing negative thoughts into positive thoughts in fostered people who are undergoing rehabilitation at the Pekanbaru Children's Special Development Institute. It is hoped that LKPA can improve cross-program and cross-sectoral cooperation including the health, social and employment agencies so that the skills acquired during coaching remain sustainable
\end{abstract}

Keyword-Applicatoin, assertive training, assertive behavior of drugs abuse

\begin{abstract}
Abstrak
Pemakaian NAPZA menjadi style (gaya hidup orang sukses) dan mekanisme koping dalam mengatasi stres dan frustasi menghadapi kehidupan serba canggih dan cepat. NAPZA adalah bahan/zat yang mempengaruhi kondisi kejiwaan/psikologi seseorang (pikiran, perasaan dan perilaku) serta dapat menimbulkan ketergantungan. Bila pemakaian NAPZA di luar dari kepentingan medis dimulai dari tahap coba-coba hingga ketergantungan karena bertentangan dengan UU No 35 tahun 2009 tentang narkotika dan UU No 5 tahun 1997 tentang psikotropika. Tujuan penelitian ini untuk mengidentifikasi pengaruh Thought Stopping terhadap proses pikir penyalahguna NAPZA di Lembaga Pembinaan Khusus Anak Pekanbaru. Manfaat penelitian ini adalah menjadi evidence base dalam pembinaan khususnya penerapan Assertive Trainning (AT)/Perilaku Asertif pada Penyalahguna NAPZA di Lembaga Pemasyarakatan Kelas IIA Pekanbaru. Pengabdian kepada Masyarakat ini dilaksanakan di Lembaga Pemasyarakatan Kelas IIA Pekanbaru pada bulan Mei-Juli 2019 dengan jumlah sampel 33 responden. Metodologi yang digunakan adalah di Lembaga Pemasyarakatan Kelas IIA Pekanbaru. Hasil pengabdian Masyarakat warga binaan dalam melakukan Assertive Trainning pada sesi 1 dan sesi 2 adalah termasuk kategori sudah terlatih, sesi 3 dan sesi 4 adalah termasuk kurang mampu atau kurang terlatih dan sesi 5 adalah termasuk agresif.
\end{abstract}

Kata kunci-Penerapan, Assertive Trainning, prilaku asertif penyalahguna NAPZA

\section{PENDAHULUAN}

\subsection{Latar Belakang}

NAPZA adalah bahan/zat yang mempengaruhi kondisi kejiwaan/psikologi seseorang (pikiran, perasaan dan perilaku) serta dapat menimbulkan ketergantungan. Penggunaan NAPZA ini legal 
bila penggunaannya sesuai dengan standar medis pengobatan akan tetapi, bila pemakaian di luar dari kepentingan medis dimulai dari tahap coba-coba hingga ketergantungan maka akan ilegal dan bertentangan dengan UU No 35 tahun 2009 tentang narkotika dan UU No 5 tahun 1997 tentang psikotropika $\left({ }^{1} ;{ }^{2} ;{ }^{3}\right)$.

Jumlah penyalahguna NAPZA menurut Direktorat Pelayanan Rehabilitasi Sosial narkoba dalam kurun tiga tahun ini meningkat $400 \%\left({ }^{3}\right)$. Hasil penelitian tahun 2008 jumlah penyalahgunaan NAPZA sebanyak 3,3 juta orang, tahun 2011 meningkat 3,8\% dan tahun 2013 mencapai 4,2 juta orang $(2,2 \%)$ yang terdiri dari pengguna coba pakai, teratur pakai, dan pecandu. Kurun waktu empat tahun terakhir, telah terungkap 108.107 kasus kejahatan NAPZA dengan tersangka sebanyak 134.117 orang. Lima provinsi dengan kasus NAPZA tertinggi di Indonesia tahun 2012 adalah Jawa Timur 7.448 kasus, DKI Jakarta 5.426 kasus, Sumatera Utara 2.420 kasus, Jawa Barat 1.252 kasus dan Jawa Tengah 1.194 kasus. Di Riau jumlah kasus NAPZA adalah 650 dan termasuk provinsi urutan keempat kasus NAPZA yang terus meningkat dalam 3 tahun terakhir setelah Kalimantan Selatan, Sulawesi Utara, Aceh dan Lampung $\left({ }^{4}\right)$.

Menurut Wahyuni dan Ma'shun (2006 dalam BNN 2009) ada tiga penyebab seseorang menyalahgunakan NAPZA yaitu faktor individu, lingkungan dan ketersediaan zat. Faktor individu seperti keinginan tinggi untuk mencoba hal baru dan tidak mampu mengelola stres. Faktor lingkungan seperti keluarga tidak harmonis, saudara juga pemakai/pengedar dan pengaruh teman sebaya. Faktor NAPZA seperti menimbulkan rasa ketagihan, mudah didapat, peredaran semakin banyak dan beragam. Individu tertarik pada obat-obatan karena membantu beradaptasi dengan lingkungan yang dinamis, memuaskan keingintahuan, mengurangi frustasi/kebosanan, lari dari kenyataan, tertarik sensasi iklannya $\left({ }^{5}\right)$, karena pengaruh teman sebaya $\left({ }^{6}\right)$, penawaran teman yang usianya sedikit lebih tua tidak memiliki keterampilan koping adaftif dan tidak berhasil membina hubungan $\left({ }^{7}\right)$. Menurut penelitian Jaji $\left({ }^{8}\right)$ didapatkan hasil faktor sosial yang mendukung seperti ingin mencoba, ikut trend, mencari kenikmatan sesaat, mencari sensasi dan rasa solidaritas yang tinggi menyebabkan remaja berisiko menyalahgunakan NAPZA sebesar $71,1 \%$. Menurut penelitian Windiarti $\left({ }^{9}\right.$ ) didapatkan hasil karena coba-coba dan bermasalah dengan teman masingmasing 53,3\% dan masalah dalam rumah tangga 40,7 \%.

Faktor individu yang menyebabkan penyalahgunaan zat adalah keingintahuan, keinginan diterima kelompok, mengikuti trend, mencari kenikmatan, mencari perhatian dan meniru orang terkenal. Menurut Martono dan Joewana $\left({ }^{10}\right)$ penyebab penyalahgunaan NAPZA adalah ingin tahu, ingin mencoba dan kecenderungan melawan otoritas untuk mencari identitas diri. Menurut Catio $\left({ }^{11}\right)$ mengatakan ikatan pergaulan yang kental dengan teman pemakai NAPZA dan frekuensi pertemuan yang sering saat menggunakan NAPZA memungkinkan seseorang termotivasi untuk mengulang kembali, meskipun telah diketahui bahkan telah merasakan efek yang tidak menyenangkan. Menurut BNN $\left({ }^{12}\right)$ kompensasi kurang adekuatnya hubungan orang tua dengan anak, kurang perhatian atau pengawasan, individu akan mencari perhatian pada kelompok.

Faktor lingkungan yang menyebabkan seseorang menyalahgunakan NAPZA adalah hubungan keluarga tidak harmonis, hubungan interpersonal yang buruk, keluarga menggunakan NAPZA dalam menyelesaikan masalah, masyarakat banyak yang menggunakan, kurang kontrol sosial dan tekanan kelompok. Menurut Palmoedojo (2005 dalam $\left.{ }^{12}\right)$ disfungsi keluarga seperti ketidakharmonisan dalam keluarga berisiko terhadap anak dengan kepribadian dan perilaku antisosial dibandingkan anak dari keluarga tanpa disfungsi. Keharmonisan dalam keluarga membutuhkan komunikasi yang baik dan harmonis antar anggota keluarga dalam bersosialisasi. Penyalahgunaan NAPZA dapat menimbulkan tanda dan gejala tertentu.

Dampak penyalahgunaan NAPZA menimbulkan berbagai konsekuensi bagi pemakainya. Pertama konsekuensi psikologis terhadap keluarga, pekerjaan dan keuangan berupa rusaknya hubungan keluarga, menurunnya prestasi belajar dan produktivitas kerja secara drastis, sulit membedakan perbuatan baik dan buruk, perubahan perilaku, menjadi sensitif dan mudah tersinggung. Kedua konsekuensi fisik yang dapat terjadi yaitu penyakit-penyakit seperti HIV/AIDS (Sullivan, Bragg, Dyehouse et al, 1995 dalam ${ }^{13}$ ). Hampir 90\% Intravena Drug User (IDU) pernah tukar-menukar atau pinjam-meminjam jarum suntik dengan temannya pecandu. Oleh karena itu penyalahguna yang telah menyuntik lebih dari 2 tahun bisa dipastikan mereka HIV positif (Kompas,2010). Ketiga konsekuensi sosial berupa kecelakaan, pelecehan, child abuse, bunuh diri, prostitusi dan tindakan kriminalitas di dalam dan di luar rumah seperti mencuri, 
merampok dan menodong $\left({ }^{14}\right), 50 \%$ fatalitas kenderaan bermotor diperkirakan akibat bermasalah dengan alkohol (Videbeck, 2008). Selain itu juga menimbulkan kematian 200 juta orang setiap tahunnya (BNN, 2009). Akibatnya penyalahguna NAPZA berisiko tinggi bermasalah dengan hukum. Untuk mengantisipasi dampak NAPZA dilakukan beberapa upaya.

Pelaksanaan terapi Assertive Trainning (AT)/Perilaku Assertif menggunakan berbagai variasi dalam membantu seseorang yang sedang mencoba dan menghentikan pikiran yang tidak menyenangkan. Terapi ini dilakukan selama 45 menit setiap muncul pikiran negatif untuk kurun waktu 2 minggu (Nursing education, practice and research, 2008). Pemberian terapi ini dapat diberikan pada seseorang yang mengalami ansietas dengan pertimbangan waktu serta kondisi klien yang akan menerima terapi.

Tujuan terapi Assertive Trainning (AT)/Perilaku Assertif adalah membantu klien mengatasi kecemasan yang mengganggu, membantu klien mengatasi pikiran negative atau mal-adaptif yang sering muncul dan membantu klien mengatasi pikiran obsesif dan fobia. Teknik penghentian pikiran paling tepat digunakan ketika pikiran disfungsional pertama mulai terjadi

Selama masa rehabilitasi dapat terjadi relaps khususnya pada tiga bulan pertama karena perasaan penyalahguna NAPZA masih ambivalent tentang abstinensi, motivasi dan komitmen tidak kuat untuk sembuh, tidak mempunyai strategi koping yang efektif dalam menghadapi masalah yang dialami selama rehabilitasi serta kurangnya dukungan dari keluarga dan orang terdekatnya (Dalley, 2001).

Lembaga Pemasyarakatan (Lapas) kelas IIA Pekanbaru adalah Lembaga Pemasyarakatan yang melakukan pembinaan pada masyarakat termasuk masalah NAPZA berupa penyuluhan tentang HIV/AIDS, hukum, pengembangan kepribadian dan keterampilan membuat sandal hotel dan tenun songket. Berdasarkan uraian di atas, maka kami ingin melakukan kegiatan "Pengabdian Masyarakat" dalam bentuk penerapan Assertive Trainning (AT) terhadap perilaku penyalahguna NAPZA di Lembaga Pemasyarakatan Kelas IIA Pekanbaru.

\subsection{Perumusan Masalah}

Berdasarkan latar belakang di atas dan mengingat pentingnya merubah proses prilalu warga binaan Lapas dalam mencegah kekambuhan maka kami tertarik untuk menerapkan Assertive Trainning (AT)/Perilaku Assertif pada penyalahguna NAPZA di Lapas Kelas II.A Pekanbaru Tahun 2019.

\subsection{Tujuan Kegiatan}

\subsubsection{Tujuan Umum}

Menerapkan Assertiveness Training (AT)/Perilaku Asertif pada Warga Binaan dengan penyalahgunaan NAPZA di Lembaga Pemasyarakatan kelas IIA Pekanbaru.

1.3.2 Tujuan Khusus

1.3.2.1 Mampu mengidentifikasi pikiran dan perasaan dan mengungkapkan pikiran, perasaan dengan cara yang tepat.

1.3.2.2 Mampu mengidentifikasi kebutuhan (sesuatu yang memang diperlukan oleh klien) dan keinginan (sesuatu yang diinginkan tapi kurang diperlukan oleh klien) dan mampu mengungkapkan dengan cara yang tepat.

1.3.2 3 Mampu mengidentifikasi penyebab marah, alasan marah, ekspresi marah yang biasa dilakukan dan dampaknya serta melatih klien cara mengekspresikan marah secara tepat yang meliputi bagaimana, mengapa dan alternatifnya.

1.3.2.4 Mampu mengidentifikasi permintaan yang tidak rasional dan alasannya, mengidentifikasi cara biasa klien menolak dan dampaknya, mengatakan "tidak" untuk permintaan yang tidak rasional dan alasan secara asertif.

1.3.2.5 Mampu memahami perilaku asertif yang telah dilatih, memahami hambatan perilaku asertif, memahami manfaat perilaku asertif dan mempertahankan perilaku asertif pada situasi yang lain. 


\subsection{Manfaat Kegiatan}

\subsubsection{Aplikatif}

Menjadi landasan bagi pihak Lembaga Pemasyarakatan (termasuk psikolog) dalam membuat kebijakan, program dan kegiatan pembinaan warga binaan Lapas terkait Assertive Trainning (AT)/Perilaku Asertif pada penyalahguna NAPZA di Lembaga Pemasyarakatan kelas IIA Pekanbaru dalam kerjasama lintas sektoral dan lintas program.

\subsubsection{Bagi Keilmuan.}

Dapat bermanfaat untuk menjadi evidence base dalam pembinaan khususnya Assertive Trainning (AT)/Perilaku Asertif pada penyalahgunaan NAPZA yang sedang menjalani pembinaan di Lembaga Pemasyarakatan Kelas IIA Pekanbaru.

\subsection{Luaran Kegiatan}

Adapun luaran dari kegiatan Pengabdian kepada Masyarakat (PkM) ini adalah Artikel Ilmiah

\section{METODE}

Metode yang digunakan dalam melakukan kegiatan pengabdian masyarakat ini adalah menggunakan metode describing, modelling, role play, feed back dan transfering. Sesi 1 (satu) sampai sesi 5 (lima) diulang satu (1) kali dan sesi 5 (lima) dilakukan satu kali. Jumlah total pertemuan 9 kali dalam 1 bulan kegiatan pengabdian masyarakat yaitu dengan melakukan kegiatan Assertive Trainning sesi 1 sampai sesi 5 masing-masing sesi memerlukan waktu lebih kurang 2 sampai 3 jam yang dilakukan pada warga binaan dengan kasus NAPZA berjumlah 33 orang. Setiap sesi kegiatan dievaluasi dan setelah selesai sesi 1 sampai dengan 5 dievaluasi secara keseluruhan terhadap kegiatan yang sudah dilaksanakan. Melakukan kegiatan Assertive Trainning ini juga didampingi oleh Kader Kesehatan yang ada di Lapas serta oleh Tamping (Tahanan Pendamping) yang turut serta dalam persiapan dan merapikan ruangan setelah kegiatan dilaksanakan serta ikut aktif dalam kegiatan.

\section{HASIL DAN PEMBAHASAN}

\section{Hasil dan Pembahasan}

Pelaksanaan kegiatan pengabdian masyarakat di Lembaga Pemasyarakatan Kelas IIA Pekanbaru diawali dengan permintaan izin dari Kepala Kantor Wilayah Kementerian Hukum dan HAM Riau yang pada prinsipnya disetujui, selanjutnya surat izin tersebut diteruskan kepada Kepala Lembaga Pemasyarakatan Kelas IIA Pekanbaru untuk pelaksanaan kegiatan pengabdian masyarakat yang dimaksud. Kepala Lembaga Pemasyarakatan Kelas IIA Pekanbaru meneruskan ke KPLP dan dari KPLP diteruskan lagi ke Kasie. Binadik yang bertanggungjawab terhadap pembinaan dan pendidikan warga binaan, karena kegiatan pengabdian masyarakat ini merupakan bidang kesehatan maka pelaksanaannya secara tekhnis diserahkan kepada dokter dan perawat yang ada di Lembaga Pemasyarakatan Kelas IIA Pekanbaru untuk mengkoordinir kegiatan tersebut.

Pelaksanaan kegiatan Pengabdian masyarakat mengenai Assertive Training pada penyalahguna NAPZA di Lembaga Pemasyarakatan Kelas IIA Pekanbaru dilakukan sebagai berikut:

1. Kegiatan permintaan izin dan penjajakan awal dilakukan pada tanggal 19 Juni 2019 di Kanwil Kemenkum HAM Riau dan Lembaga Pemasyarakatan Kelas IIA Pekanbaru untuk melakukan koordinasi terhadap pelaksanaan kegiatan pengabdian masyarakat.

2. Tanggal 01 Juli 2019 dilakukan kegiatan pembukaan yang dibuka oleh Penangung Jawab Poliklinik Lembaga Pemasyarakatan Kelas IIA Pekanbaru dan dimulainya kegiatan Sesi 1.

Sebelum kegiatan pertemuan pertama ini dilakukan, tim pengabdian masyarakat melakukan konfirmasi dengan penanggung jawab poliklinik Lembaga Pemasyarakatan Kelas IIA Pekanbaru guna mendapatkan kepastian jam pembukaan dan pelaksanaan sesi 1 .

Acara pembukaan pengabdian masyarakat ini bertujuan memberikan gambaran kegiatan Asertive Trainning (AT) secara umum yaitu penjelasan tentang pengertian, tujuan, kontrak kegiatan dan penandatanganan informed concent warga binaan. Warga binaan yang setuju menjadi partisipan pada Pengabdian kepada Masyarakat (PkM) akan mendapatkan buku kerja 
dan ballpoint. Setelah itu warga binaan diminta untuk mengisi data-data demografi antara lain : nama, tempat/tanggal lahir, agama, pendidikan, alamat, lama pemakaian NAPZA, alasan menyalahgunakan NAPZA, anggota keluarga terdekat yang juga pemakai, lama vonis dan sisa lama hukuman yang dijalani. Kegiatan pada pelaksanaan sesi 1 ini adalah Pengenalan diri, sikap, perilaku asertif dan latihan asertif warga binaan. Tujuan dari sesi 1 ini adalah agar warga binaan mampu mengidentifikasi pikiran, perasaan dan mengungkapkan pikiran, perasaan dengan cara yang tepat. Pada sesi 1 ini warga binaan dilatih untuk menuliskan pada buku kerja lima kejadian dalam 1 minggu terakhir 5 (lima) kejadian yang membuat warga binaan suges yang selanjutnya penulis modifikasi menjadi 5 (lima) kejadian yang membuat warga binaan kesal/jengkel/bad mood. Tujuan tim PkM memodifikasi latihan ini adalah agar warga binaan tidak memaksakan diri menjadi tersugesti karena berdampak negatif mengingat warga binaan adalah banyak yang sudah dalam tahap rehabilitasi. Tehnik pelaksanaan sesi 1 melalui describing, modelling, role playing, feedback, transferring. Kegiatan sesi 1 ini dilakukan di ruangan Aula Lapas. Warga binaan dijelaskan tentang pengertian, indikasi, tujuan/manfaat dan tehnik pelaksanaan Asertive Trainning (AT). Setelah tim PkM yakin bahwa warga binaan memahami Asertive Trainning (AT) ini baru warga binaan dibimbing mengisi buku kerja halaman 2 dan 3.

Berikut ini ditampilkan data demografi warga binaan peserta Assertive Trainning yang disajikan dalam bentuk tabel sebagai berikut :

Tabel 4. 1 Distribusi Frekuensi Responden Penyalahgunaan NAPZA Berdasarkan Usia Tahun $2019(n=2019)$

\begin{tabular}{llcc}
\hline No. & \multicolumn{1}{c}{ Kategori Usia } & Frekuensi (orang) & Persentase $(\%)$ \\
\hline 1. & Remaja Awal (12-16 tahun) & & - \\
2. & Remaja Akhir (17-25 tahun) & 2 & 6,1 \\
3. & Dewasa $\geq 26$ tahun) & 31 & 93,9 \\
\hline & Total & 33 orang & 100 \\
\hline
\end{tabular}

Dari tabel 4.1 di atas bahwa distribusi warga binaan penyalahgunaan NAPZA berdasarkan usia yang terbanyak adalah kategori usia dewasa ( $\geq 26$ tahun) sebanyak 31 orang atau 93,9\%.

Tabel 4.2 Distribusi Frekuensi Responden Penyalahgunaan NAPZA Berdasarkan Pendidikan

\begin{tabular}{clcc}
\multicolumn{4}{c}{ Tahun $2019(\mathrm{n}=2019)$} \\
No. & Pendidikan & 5 & \\
\hline 1. & SD & 10 & 15,2 \\
2. & SLTP & 17 & 30,3 \\
3. & SMA/SMK/SMU & 1 & 51,5 \\
4. & $\geq$ D III & 33 orang & 3,0 \\
\hline & Total & Prekuensi (orang) & 100 \\
\hline
\end{tabular}

Dari tabel 4.2 tersebut di atas bahwa mayoritas pendidikan warga binaan penyalahgunaan NAPZA terbanyak adalah berpendidikan SMA/SMK/SMU yaitu sebanyak 17 orang atau 51,5\%.

Tabel 4.3 Distribusi Frekuensi Responden Penyalahgunaan NAPZA Berdasarkan Agama Tahun

\begin{tabular}{clcc}
\multicolumn{5}{c}{$2019(\mathrm{n}=2019)$} \\
\hline No. & Pendidikan & Frekuensi (orang) & Persentase $(\%)$ \\
\hline 1. & Islam & 33 & 100 \\
2. & Kristen Khatolik & - & - \\
3. & Kristen Protestan & - & - \\
4. & Hindu & - & - \\
\hline & Total & 33 orang & 100 \\
\hline
\end{tabular}

Berdasarkan Tabel 4.3, seluruh warga binaan penyalahgunaan NAPZA agamanya adalah menganut agama islam yaitu 33 orang atau $100 \%$. 
DINAMISIA - Jurnal Pengabdian Kepada Masyarakat Vol. 3, No. 2 Desember 2019, Hal. 319-329

Tabel 4.4 Distribusi Frekuensi Responden Berdasarkan Lamanya Pemakaian NAPZA Tahun

\begin{tabular}{ccccc}
\multicolumn{5}{c}{$2019(\mathrm{n}=33)$} \\
\hline No. & & Lamanya & Frekuensi (orang) & Persentase $(\%)$ \\
\hline 1. & $\leq 3$ tahun & 16 & 48,5 \\
2. & $4-8$ tahun & 9 & 27,3 \\
3. & $9-12$ tahun & 5 & 15,2 \\
4. & $\geq 13$ tahun & & 3 & 9,1 \\
\hline & & Total & 33 orang & 100
\end{tabular}

Tabel 4.4 tersebut di atas mayoritas warga binaan lama pemakaian NAPZA yang terbanyak adalah $\leq 3$ tahun berjumlah 16 orang atau $48,5 \%$.

Tabel 4.5 Distribusi Frekuensi Responden Berdasarkan Alasan Menggunakan NAPZA Tahun $2019(n=33)$

\begin{tabular}{clcc}
\hline No. & Alasan Menggunakan NAPZA & Frekuensi (orang) & Persentase (\%) \\
\hline 1. & Faktor Individu & 12 & 36,4 \\
2. & Faktor Lingkungan & 13 & 39,4 \\
3. & Faktor Zat itu sendiri & 8 & 24,2 \\
\hline \multicolumn{2}{r}{ Total } & 33 orang & $100 \%$ \\
\hline
\end{tabular}

Tabel 4.5 di atas mayoritas alasan warga binaan menyalahgunakan NAPZA adalah faktor lingkungan yaitu 13 orang atau $39,4 \%$.

Tabel 4.6 Distribusi Frekuensi Responden Berdasarkan Anggota Keluarga Menggunakan NAPZA Tahun $2019(n=33)$

\begin{tabular}{ccccc}
\hline No. & \multicolumn{2}{c}{ Angota keluarga yang Menggunakan } & Frekuensi (orang) & Persentase (\%) \\
& \multicolumn{2}{c}{ NAPZA } & & \\
\hline 1. & Ada & & 6 & 18,2 \\
2. & Tidak ada & & 27 & 81,8 \\
\hline & & Total & 33 orang & $100 \%$ \\
\hline
\end{tabular}

Berdasarkan tabel 4.6 mayoritas responden tidak memiliki warga binaan yang juga menyalahgunakan NAPZA yaitu 27 orang atau $81,8 \%$.

Tabel 4.7 Distribusi Frekuensi Responden Berdasarkan Sisa Lama Hukuman Tahun 2019 (n=33)

\begin{tabular}{|c|c|c|c|}
\hline No. & Sisa Lama Hukuman & Frekuensi (orang) & Persentase (\%) \\
\hline 1. & $\leq 1$ tahun & 6 & 18,2 \\
\hline 2. & 2 tahun & 10 & 30,3 \\
\hline 3. & 3 tahun & 6 & 18,2 \\
\hline 4. & $\geq 4$ tahun & 11 & 33,3 \\
\hline & Total & 33 orang & 100 \\
\hline
\end{tabular}

Tabel 4.5 di atas mayoritas sisa lama hukuman yang harus dijalani warga binaan adalah $\geq 4$ tahun yaitu 11 orang atau $33,3 \%$.

Tabel 4.8 Distribusi Frekuensi Responden Berdasarkan Kemampuan melakukan Assertive Trainning Sesi 1 Tahun $2019(\mathrm{n}=33)$

\begin{tabular}{|c|c|c|c|}
\hline No & $\begin{array}{c}\text { Kategori Kemampuan berlatih Assertive } \\
\text { Trainning sesi } 1\end{array}$ & Frekuensi (orang) & Persentase $(\%)$ \\
\hline 1. & Mampu & 21 & 64 \\
\hline 2. & Kurang Mampu & 12 & 36 \\
\hline & Total & 33 orang & 100 \\
\hline
\end{tabular}

Tabel 4.8 di atas mayoritas kemampuan warga binaan berlatih sesi 1 tergolong kategori mampu yaitu 21 orang atau $64 \%$. 
3. Tanggal 03 Juli 2019 dilakukan pertemuan kedua. Tujuan pertemuan ini adalah menilai/mengevaluasi kemampuan warga binaan sesi 1 yang sudah dijelaskan 2 hari sebelumnya. Kegiatan ini dilakukan agar mengetahui jumlah warga binaan yang belum mengisi 5 (lima) kejadian yang membuat warga binaan kesal/jengkel/bad mood karena jika ada warga binaan yang belum mampu sesi 1, tidak dapat mengikuti sesi 2. Jika ada warga binaan yang belum terlatih menyebutkan/menuliskan pada buku kerja lima kejadian dalam 1 minggu terakhir 5 (lima) kejadian yang membuat warga binaan suges/kesal/jengkel/bad mood. Hasil evaluasi sesi 1 ini adalah sebagian besar warga binaan sudah mampu menuliskan 3-4 kejadian yang membuat mereka suges/kesal/jengkel/bad mood artinya warga binaan mampu mengidentifikasi pikiran, perasaan dan mengungkapkan pikiran, perasaan dengan cara yang tepat. Hal ini didukung dengan hasil PkM pada tabel 4.2 bahwa mayoritas pendidikan warga binaan penyalahgunaan NAPZA terbanyak adalah berpendidikan SMA/SMK/SMU yaitu sebanyak 17 orang atau 51,5\%, dimana seseorang yang pendidikan SMA/SMK/SMU adalah termasuk jenjang pendidikan menengah yang dapat menerima suatu pemabaruan/pengetahuan.

4. Tanggal 09 Juli 2019 dilakukan pertemuan ketiga yaitu pelaksanaan Sesi 2. Tujuan pertemuan ini agar warga binaan mampu mengidentifikasi kebutuhan (sesuatu yang memang diperlukan) dan keinginan (sesuatu yang diinginkan tapi kurang diperlukan) dan mampu mengungkapkan dengan cara yang tepat.

Bentuk kegiatannya adalah penjelasan perbedaan kebutuhan, keinginan dan cara memenuhi kebutuhan/keinginan tersebut secara asertif lalu warga binaan secara acak dilatih untuk menyebutkan contoh kebutuhan dan keinginan yang paling diingat/berkesan dalam seminggu terakhir. Kegiatan ini dilakukan pada 2-3 warga binaan sampai tim Pengabdian kepada Masyarakat $(\mathrm{PkM})$ yakin semua warga binaan telah paham cara melakukan sesi 2. Selanjutnya warga binaan dilatih untuk menuliskan kebutuhan dan keinginan lainnya serta cara memenuhinya secara asertif secara pada buku kerja halaman 5 dan 6.

Tabel 4.9 Distribusi Frekuensi Responden Berdasarkan Kemampuan melakukan Assertive Trainning Sesi 2 Tahun 2019 ( $\mathrm{n}=33$ )

\begin{tabular}{cccc} 
No & $\begin{array}{c}\text { Kategori Kemampuan berlatih Assertive } \\
\text { Trainning sesi 2 }\end{array}$ & Frekuensi (orang) & Persentase (\%) \\
\hline 1. & Mampu & 14 & 42 \\
2. & Kurang Mampu & 19 & 58 \\
\hline \multicolumn{2}{c}{ Total } & 33 orang & 100 \\
\hline
\end{tabular}

Tabel 4.9 di atas mayoritas kemampuan warga binaan berlatih sesi 1 tergolong kategori kurang mampu yaitu 19 orang atau $58 \%$.

5. Tanggal 11 Juli 2019 dilakukan evaluasi sesi 2. Tujuan pertemuan ini adalah menilai/mengevaluasi kemampuan warga binaan mengidentifikasi kebutuhan (sesuatu yang memang diperlukan) dan keinginan (sesuatu yang diinginkan tapi kurang diperlukan) dan mampu mengungkapkan dengan cara yang tepat. Hasil sesi 2 ini sebagian besar warga binaan belum dapat membedakan antara kebutuhan dengan keinginan dan sebagian besarnya cara memenuhi tidak secara asertif namun lebih banyak secara agresif. Menurut analisa tim PkM hal ini disebabkan karena semua warga binaan adalah laki-laki yang lebih dominan memiliki sifat agresif (kasar dalam berperilaku) dan situasi lingkungan Lapas yang penuh sesak.

6. Tanggal 16 Juli 2019 dilakukan kegiatan sesi 3. Kegiatan yang dilakukan pada sesi 3 ini adalah warga binaan dilatih untuk mengidentifikasi penyebab marah, alasan, ekspresi marah yang biasa dilakukan, dampaknya dan melatih klien cara mengekspresikan marah secara tepat yang meliputi bagaimana, mengapa dan alternatif pemecahan masalahnya.

Kegiatan ini juga dilakukan di ruang Aula Lapas dengan cara warga binaan dijelaskan penyebab, alasan, ekspresi, dampak marah dan alternatif pemecahan masalah. Untuk memastikan bahwa warga binaan telah memahami sesi ini maka warga diminta menjelaskan ulang dan memberikan contoh sesi ini secara acak. Setelah itu warga binaan dibimbing menuliskannya di buku kerja minimal 4 dari 7 kolom yang tersedia dan sisanya dapat dilanjutkan di kamar blok masingmasing. 
DINAMISIA - Jurnal Pengabdian Kepada Masyarakat Vol. 3, No. 2 Desember 2019, Hal. 319-329

Tabel 4.10 Distribusi Frekuensi Responden Berdasarkan Kemampuan melakukan Assertive Trainning Sesi 3 Tahun $2019(\mathrm{n}=33)$

\begin{tabular}{cccc}
\hline No & $\begin{array}{c}\text { Kategori Kemampuan berlatih Assertive } \\
\text { Trainning sesi 3 }\end{array}$ & Frekuensi (orang) & Persentase (\%) \\
\hline 1. & Mampu & 15 & 45 \\
2. & Kurang Mampu & 18 & 55 \\
\hline & Total & 33 orang & 100 \\
\hline
\end{tabular}

Tabel 4.10 di atas mayoritas kemampuan warga binaan berlatih sesi 3 tergolong kategori kurang mampu yaitu 18 orang atau $55 \%$.

7. Tanggal 18 Juli 2019 dilakukan evaluasi Sesi 3. Tujuan pertemuan ini adalah menilai/mengevaluasi kemampuan warga binaan mengidentifikasi penyebab marah, alasan, ekspresi marah yang biasa dilakukan, dampaknya dan melatih cara mengekspresikan marah secara tepat yang meliputi bagaimana, mengapa dan alternatif pemecahan masalahnya. Hasil sesi 3 adalah hampir sama dengan sesi 2 yaitu sebagian besar warga binaan mengekspresikan marahnya dengan cara agresif hanya sebagian kecil yang asertif. Analisa tim PkM didukung dengan hasil tabel 4.4 yaitu mayoritas warga binaan lama pemakaian NAPZA yang terbanyak adalah $\leq 3$ tahun berjumlah 16 orang atau $48,5 \%$. NAPZA telah merubah perilaku seseorang yang karena kecanduannya menjadi agresif karena untuk melakukan berbagai macam cara agar keinginannya terpenuhi secara cepat (yang jika tidak terpenuhi maka cenderung marah/agresif). Hal ini sejalan dengan teori yang menyebutkan bahwa dampak penyalahgunaan NAPZA menimbulkan berbagai konsekuensi bagi pemakainya. Pertama konsekuensi psikologis terhadap keluarga, pekerjaan dan keuangan berupa rusaknya hubungan keluarga, menurunnya prestasi belajar dan produktivitas kerja secara drastis, sulit membedakan perbuatan baik dan buruk, perubahan perilaku, menjadi sensitif dan mudah tersinggung. Hasil PkM ini juga didukung dengan data pada tabel 4.1 bahwa mayoritas warga binaan penyalahgunaan NAPZA berdasarkan usia yang terbanyak adalah kategori usia dewasa ( $\geq 26$ tahun) sebanyak 31 orang atau 93,9\%. Karakter/prilaku seseorang yang tergolong usia dewasa sudah terbentuk sedemikian rupa sehingga menurut analisa tim PkM tidak mudah dirubah dengan cepat.

8. Tanggal 23 Juli 2019 dilakukan kegiatan Sesi 4.

Kegiatan yang dilakukan pada sesi 4 ini adalah warga binaan dilatih untuk mengatakan "tidak" untuk permintaan yang tidak rasional dan menyampaikan alasan. Tehnik pelaksanaan sesi 4 ini adalah dengan cara melatih warga binaan untuk mengidentifikasi permintaan yang tidak rasional dan alasannya, mengidentifikasi cara biasa menolak dan dampaknya, mengatakan "tidak" untuk permintaan yang tidak rasional dan alasan namun secara asertif.

Kegiatan pada sesi 4 ini diawali dengan review sesi 3 dan penjelasan sesi 4 tentang cara menolak suatu permintaan dan keinginan orang lain tanpa oranglain tersebut menjadi jengkel. Untuk lebih memahami sesi 4 ini, warga binaan secara acak diminta melakukan hal yang sama. Hal ini dapat dilakukan beberapa kali sampai tim PkM yakin warga binaan mengerti sesi ini. Setelah itu, warga binaan dibimbing untuk menuangkannya pada buku kerja halaman 8. Jika warga binaan sudah mampu mengisi 4 dari 7 kolom yang tersedia maka tim PkM mengakhiri sesi ini dan warga binaan dapat melanjutkannya di kamar blok masing-masing dan mereka dapat saling berdiskusi namun sesuai dengan masalah per individu.

Tabel 4.11 Distribusi Frekuensi Responden Berdasarkan Kemampuan melakukan Assertive Trainning Sesi 4 Tahun 2019 ( $\mathrm{n}=33$ )

\begin{tabular}{|c|c|c|c|}
\hline No & $\begin{array}{c}\text { Kategori Kemampuan berlatih Assertive } \\
\text { Trainning sesi } 4\end{array}$ & Frekuensi (orang) & Persentase (\%) \\
\hline 1. & Mampu & 15 & 45 \\
\hline 2. & Kurang Mampu & 18 & 55 \\
\hline & Total & 33 orang & 100 \\
\hline
\end{tabular}

Tabel 4.11 di atas mayoritas kemampuan warga binaan berlatih sesi 4 tergolong kategori kurang mampu yaitu 18 orang atau $55 \%$. 
9. Tanggal 25 Juli 2019 dilakukan evaluasi Sesi 4.

Tujuan pertemuan ini adalah menilai/mengevaluasi kemampuan warga binaan mengatakan "tidak" untuk permintaan yang tidak rasional dan menyampaikan alasan.

Hasil sesi 4 ini adalah sebagian besar warga binaan telah dapat mengidentifikasi permintaan yang tidak rasional dan alasannya, namun cara menolak suatu permintaan dan keinginan orang lain tanpa oranglain tersebut menjadi jengkel belumlah maksimal (artinya tetap oranglain menjadi jengkel). Analisa tim PkM untuk hasil sesi 4 ini adalah memang sulit untuk menolak permintaan seseorang yang sudah mengenal dengan diri kita. Warga binaan yang menjadi khalayak sasaran PkM ini adalah warga binaan yang sedang menjalani masa hukuman sudah bertahun-tahun dan mereka tinggal di kamar blok yang sama. Hasil PkM ini didukung sejalan dengan hasil tabel 4.5 mayoritas sisa lama hukuman yang harus dijalani warga binaan adalah $\geq 4$ tahun yaitu 11 orang atau $33,3 \%$.

Tabel 4.12 Distribusi Frekuensi Responden Berdasarkan Kemampuan melakukan Assertive Trainning sesi 5 Tahun $2019(\mathrm{n}=33)$

\begin{tabular}{ccccc}
\hline No & \multicolumn{2}{c}{ Kategori Kemampuan berlatih Assertive } \\
& \multicolumn{1}{c}{ Trainning sesi 5 } & Frekuensi (orang) & Persentase (\%) \\
\hline 1. & Asertif & 15 & 45 \\
2. & Pasif & 5 & 15 \\
3. & Agresif & & 13 & 40 \\
\hline & & Total & 33 orang & 100 \\
\hline
\end{tabular}

Tabel 4.12 di atas mayoritas kemampuan warga binaan berlatih sesi 4 tergolong kategori kurang mampu yaitu 18 orang atau 55\%.

10.Tanggal 30 Juli 2019 kegiatan Sesi 5 sekaligus acara penutupan kegiatan.

Kegiatan yang dilakukan pada sesi 5 ini adalah warga binaan dilatih untuk memahami perilaku asertif yang telah dilatih, memahami hambatan perilaku asertif, memahami manfaat perilaku asertif dan mempertahankan perilaku asertif pada berbagai situasi.

Kegiatan yang dilakukan pada sesi ini tetap seperti sesi-sesi sebelumnya dimana dilakuan terlebih dahulu evaluasi sesi 1/sesi 2/sesi 3 atau sesi 4, selanjutnya warga dijelaskan perbedaan perilaku kategori agresif, pasif dan asertif. Kegiatan berikutnya pada sesi 5 ini adalah warga binaan dilatih untuk menentukan sendiri kategori agresif, pasif dan asertif. Kegiatan ini juga menekankan bahwa warga binaan diminta jujur untuk menentukan condong termasuk ke kategori manakah prilaku mereka dalam seminggu terakhir tanpa merasa takut dampak kategori prilaku terhadap penilaian petugas lapas pada diri mereka masing-masing.

Hasil sesi ini mayoritas warga binaan adalah tergolong prilakunya asertif walaupun angka agresif juga termasuk tinggi, namun yang terpenting secara asertif mengakui kelemahan dan kekurangan yang ada pada diri seseorang.

Pelaksanaan kegiatan pengabdian masyarakat ini dilakukan juga monitoring dan evaluasi yang ditunjuk oleh Unit UPPPM Poltekkes Kemenkes Riau dan oleh dua orang Reviewer sesuai dengan tim reviewer pada saat seminar proposal pengabdian masyarakat sehingga kegiatan ini dapat dimonitor dari awal (sesuai dengan proposal yang diajukan), saat pelaksanaan kegiatan dan di akhir (seminar laporan akhir Pengabdian Masyarakat). Monitoring dan evaluasi yang ditunjuk UP3M Poltekkes Kemenkes Riau dilakukan oleh Yanti, SST, M.Keb pada tanggal 16 Juli 2019 sedangkan dua orang Reviewer yang melakukan monitoring dan evaluasi adalan Ns. Wiwiek Delvira, S.Kep, M.Kep tanggal 18 Juli 2019 dan Yessi Alza, SST, M. Biomed pada tanggal 23 Juli 2019.

\section{KESIMPULAN}

1. Mayoritas kemampuan warga binaan melakukan Assertive Trainning (AT) sesi 1 (mengidentifikasi pikiran, melatih kemampuan pengenalan diri, dan perasaan, mengungkapkan pikiran, perasaan, mengubah pikiran dengan cara yang tepat) adalah sudah terlatih atau mampu

2. Mayoritas kemampuan warga binaan melakukan Assertive Trainning (AT) sesi 2 (kemampuan mengidentifikasi dan melatih kemampuan mengungkapkan kebutuhan (sesuatu yang memang diperlukan oleh klien) dan keinginan (sesuatu yang diinginkan tapi kurang 
diperlukan oleh klien) dan mampu mengungkapkan dengan cara yang tepat adalah adalah sudah terlatih atau mampu

3. Mayoritas kemampuan warga binaan melakukan Assertive Trainning (AT) sesi 3 (kemampuan mengidentifikasi penyebab marah, alasan marah, ekspresi marah yang biasa dilakukan dan dampaknya serta melatih klien cara mengekspresikan marah secara tepat yang meliputi bagaimana, mengapa dan alternatifnya serta kemampuan menjalin hubungan sosial dalam memenuhi kebutuhan) adalah kurang mampu atau kurang terlatih.

4. Mayoritas kemampuan warga binaan melakukan Assertive Trainning (AT) sesi 4 (kemampuan mengidentifikasi permintaan yang tidak rasional dan alasannya, mengidentifikasi cara biasa klien menolak dan dampaknya, mengatakan "tidak" untuk permintaan yang tidak rasional dan alasan secara asertif) adalah kurang mampu atau kurang terlatih

5. 4.5 Mayoritas kemampuan warga binaan melakukan Assertive Trainning (AT) sesi 5 (kemampuan memahami perilaku asertif yang telah dilatih, memahami hambatan perilaku asertif, memahami manfaat perilaku asertif dan mempertahankan perilaku asertif pada situasi yang dan latihan mempertahankan perubahan assertive dalam berbagai situasi) adalah agresif dan asertif.

\section{SARAN}

1. Kepada pihak Lembaga Pemasyarakatan Kelas IIA Pekanbaru khususnya Bagian rehabilitasi, hendaknya betul-betul segenap usaha, pemikiran dan perhatian senantiasa dicurahkan pada warga binaan, meningkatkan perhatian karena walaupun mereka terkesan diam dan patuh serta menuruti apa yang dianjurkan namun dibalik itu mereka tidak pernah betul-betul melupakan dan bertaubat atas kesalahan yang mereka lakukan sebelum masuk di LP, hal ini terlihat dari catatan-catatan yang mereka buat, jika memungkinkan dan jika tidak menyalahi aturan beri mereka pekerjaan dan latihan yang sebanyak-banyaknya sehingga mereka mengeluarkan energi dan menimbulkan rasa capek sehingga akhirnya mereka dapat mengalihkan dari pikiran yang negatif menjadi pikiran yang positif.

2. 5.2 Kepada sejawat tenaga kesehatan semua termasuk dokter, jangan putus asa dan harus meningkatkan kesabaran dalam menghadapi warga binaan umumnya dan khususnya pada pecandu NAPZA, karena walaupun mereka tahu dan paham bahwa narkoba itu merusak segala sistem yang ada di dalam tubuhnya, namun dalam pikiran mereka selalu berkecamuk bagaimana untuk memperoleh dan mendapatkan barang haram tersebut, termasuk mereka yang di LP. Kita tidak boleh lengah sedikitpun, mereka yang sudah bebas sekalipun tidak menutup kemungkinan akan mensuplai teman-temannya di LP. Untuk itu harus waspada juga pada warga binaan dengan kasus NAPZA yang sudah bebas.

3. 5.3 Kepada petugas penjagaan di Lembaga Pemasyarakatan Kelas IIA Pekanbaru, Assertive Training dapat menekan sedikit dari sikap agresif menjadi assertive, namun sebenarnya cukup membantu agar mereka lebih menjadi assertive, untuk itu diterapkan dalam kehidupan mereka sehari-hari terutama pada warga binaan di Bagian Rehabilitasi dan umumnya di Lembaga Pemasyarakatan

\section{UCAPAN TERIMA KASIH}

Selama proses penyusunan laporan akhir Pengabdian kepada Masyarakat (PkM) ini, penulis tidak lepas dari bimbingan, dukungan dan arahan dari berbagai pihak, oleh sebab itu pada kesempatan ini penulis menyampaikan ucapan terima kasih kepada:

1. Bapak Husnan, SKp, MKM, selaku Direktur Poltekkes Kemenkes Riau.

2. Bapak Yulius Sahruzah, Bc.IP, S.H., M.H, Selaku Kepala Lapas Kelas IIA Pekanbaru

3. Hj. Rusherina, SPd, S.Kep., M.Kes, selaku Ketua Jurusan Keperawatan Poltekkes Kemenkes Riau.

4. Ns. Wiwiek Delvira M.Kep dan Yess Alza, SST, M.Biomed, selaku reviewer I dan II yang telah membantu selama proses kegiatan PkM ini

5. Dosen dan staf di Prodi DIV Keperawatan Poltekkes Kemenkes yang telah banyak memberikan berbagai lmu selama proses penyusunan laporan Akhir ini. 
6. Teristimewa rasa hormat dan terima kasih yang tidak terhingga kepada Ayahanda dan Ibunda, suami dan anak-anakku tercinta (Andyny, Fadila dan Zaskia) dan seluruh keluarga yang telah memberikan bantuan moril, materil, doa dan motivasi yang tiada henti-hentinya dalam menyelesaikan laporan akhir pengabdian masyarakat ini.

7. Serta teman satu tim pengabmasy Poltekkes Kemenkes Riau Jurusan Keperawatan Tahun 2019, yang telah memberikan motivasi, masukan dan kebersamaannya selama ini.

Penulis menyadari laporan akhir pengabdian masyarakat ini tidak terlepas dari kesalahan dan kekurangan. Penulis sangat mengharapkan kritik dan saran yang sifatnya membangun demi kesempurnaan laporan ini serta perbaikan di masa mendatang. Akhir kata semoga laporan ini bermanfaat bagi semua.

\section{DAFTAR PUSTAKA}

[1] Joewana, S. (2005). Gangguan Mental dan Perilaku Akibat Penggunaan Zat Psikoaktif: Penyalahgunaan NAPZA/Narkoba (edisi 2), Jakarta: EGC

[2] Ramadhani, S. (2007). Sukses Tanpa Narkoba, Bandung, CV Armico

[3] Mardani. (2008). Penyalahgunaan Narkoba dalam Perspekif Hukum Islam dan Hukum Pidana Nasional. Jakarta: PT Raja Grafindo Persada.

[4] Santrock J.W (2007). Remaja. (Edisi 11 jilid 2), Jakarta : Penerbit Erlangga

[5] Videbeck, S. (2008). Buku Ajar Keperawatan Jiwa. Jakarta.EGC

[6] Jaji. (2009). Hubungan Faktor Sosial dan Spiritual dengan Resiko Penyalahgunaan NAPZA pada Remaja SMP dan SMA di Kota Palembang. Jakarta : FK UI

[7] Martono, L.H \& Joewana, S. (2006). Masa Remaja Cenderung Rawan Menggunakan Narkoba. Sadar Aware \& Care, Majalah bulanan narkotika nasional. 08 (IV), 34-37

[8] Catio, M. (2006), Pencegahan dan Penanggulangan Penyelahgunaan Narkoba, Jakarta

[9] Roseline, T. (2010). Hubungan Faktor Individu dan Lingkungan dengan Perilaku Penggunaan NAPZA pada Remaja di Balai Pemulihan Sosial Pamardhi Putra Lembang Bandung, Jakarta : FK UI

[10] Sartika, D (2010). Pengaruh Relapse Prevention Training Terhadap Kekambuhan dan Kepatuhan Klien Ketergantungan Heroin yang Menjalani Program Terapi Rumatan Metadon di DKI. Jakarta : FK UI

[11] Ma'aruf, S. (2006). Pencegahan Narkoba dari Keluarga Hingga Masyarakat dari Pusat hingga Daerah, Majalah bulanan narional, 08 (IV), 34-47

[12] Departemen Kesehatan RI, Undang-Undang Republik Indonesia nomor 35 tahun 2009 tentang Narkotika. Departemen Kesehatan Republik Indonesia, Jakarta

[13] Nurdin, A.E (2011). Keluarga dan Penyalahguna Zat Psikoaktif Endemik Sumatera, Padang

[14] Pencegahan dan Pemberantasan Penyalahgunaan dan Peredaran Gelap Narkoba (P4GN) Edisi tahun 2014 dan data Ditjen Pemasyarakatan Kementerian Hukum dan HAM RI (2014)

[15] Rustyawati. (2010), Beberapa Faktor Resiko yang Berhubungan dengan Penyalahguna Narkoba pada Penderita yang Dirawat di Panti Rehabiitasi, Semarang 